\title{
GRAFFITI ART COPYRIGHT PROTECTION IN BRAZIL: A SHORT ANALYSIS
}

\section{Pedro Marcos Nunes Barbosa ${ }^{1}$}

Raul Murad Ribeiro de Castro²

Keywords: Graffiti, Art, Property Law, Aesthetic Politics, Environment.

\section{INTRODUCTION}

Legal discussions concerning graffiti in Brazil have historically taken a criminal law approach. Since the 1980s, and throughout the 1990s, most of the case law and doctrine related to (i) the type of crime involved in unauthorized alteration of another's private property ${ }^{3}$ or on public venues ${ }^{4}$ and buildings ${ }^{5}$; (ii) if a property owner could be awarded exemplary/moral damages $^{6}$; or (iii) if this act would be considered a misdemeanor, when a minor was the responsible for the graffiti ${ }^{7}$.

Considering the sunset of a twenty one year military dictatorship in Brazil, fulfilled with superficial, sophist, moral and religious agenda, it was no surprise that the graffiti received an illegal-social stigmatization, generally viewed as a favela (slums) movement or a gang related

\footnotetext{
${ }^{1}$ Doutor em Direito (USP), Mestre em Direito (UERJ), Especialista em Propriedade Intelectual (PUC-Rio). Professor do Departamento de Direito da PUC-Rio. Sócio de Denis Borges Barbosa Advogados. E-mail: pedromarcos@nbb.com.br.

${ }^{2}$ Doutorando e Mestre em Direito (UERJ).E-mail: raulmurad@nbb.com.br

3 "However, the law regime of property is the regime of exclusion: exclusion of some em relation to the assets and their product and of work" (free translation of) LOPES, José Reinaldo de Lima. O Direito na História. 4a Edição, São Paulo: Editora Atlas, 2012, p. 386.

${ }^{4}$ In an illegal election propaganda case, the Supreme Federal Court dismissed a criminal inquiry against a congressman that had produced graffiti on a federal highway with his 'data' to attract votes: Supreme Federal Court, Pleno, Justice Carlos Madeira, Inq. 321-2, decided in 09.02.1987.

${ }^{5}$ In an interesting habeas corpus ruled by the Supreme Federal Court, a lieutenant was accused of graffiting (therefore being accountable for the damage crime) "Diretas Já", meaning "Direct Elections Promptly", on the barracks wall, during the Dictatorship period that governed Brazil since the 1960's. Ex officio the Court decided to interrupt the police inquiry: Supreme Federal Court, 1aㅡ Turma, Justice Néri da Silveira, HC 63260-2, Ruled in 09.10.1985.

${ }^{6}$ On a free translation: "Graffiti on a private property wall, quickly painted by the public cleaning company doesn't generate moral damages award". State Court of the State of Rio de Janeiro (TJRJ), 16a Câmara Cível, Des. Nascimento Póvoas, docket number (civil appeal) 00258725219998190000, Ruled on 06.27.2002.

${ }^{7}$ MANCUSO, Rodolfo de Camargo. Aspectos jurídicos da chamada "pichação" e sobre a utilização da ação civil pública para tutela do interesse difuso à proteção da estética urbana. Revista da Faculdade de Direito, Universidade de São Paulo, São Paulo, v. 87, p. 155-181, jan. 1992. ISSN 2318-8235. Disponível em: <https://www.periodicos.usp.br/rfdusp/article/view/67173>. Acesso em: 12 jan. 2018. doi:http://dx.doi.org/10.11606/issn.2318-8235.v87i0p155-181.
} 
activity. Therefore, the popular name in Portuguese for this kind of human manifestation was considered "pichar" or "piche" which means tar, with a semiotic presumption of a dirty, naughty, nasty practice.

Although the late 90's brought a popular goodwill towards graffiti's existence as a 'new' form of art, assaults ${ }^{8}$ against historical features such as the Christ in Rio de Janeiro, maintained over the practice a shadow of prejudice against its practitioners. Wherefore, in 1998 the Federal Law 9.605 was implemented by Congress to sanction any conduct that could be considered to impact the environment, with a specific chapter ${ }^{9}$ concerning graffiti on private or public properties, and penalties that involved fines and up to one year prison-detention time.

This brief context is important, however, to expose the content that will not be approached by this paper. In fact, the proposal of this article is to analyze the current status of graffiti art manifestation, the public policies related, and to realize a short and precise aesthetic study of the matter in Brazil.

\section{VISUAL POLUTION, ART AND GRAFFITI}

A conservative ${ }^{10}$ lens throughout the extension of real estate property rights in Brazil would, exclusively, consider a literal/fetishist ${ }^{11}$ approach of the 2002 Brazilian Civil Law Code (BCC) article 1.228. Therefore, a complete and final view of the issue would analyze unauthorized graffiti as a direct violation against ownership since : "The owner has the right to use, enjoy and to dispose of the asset, and the right to retrieve its property of the power

\footnotetext{
${ }^{8}$ In 1991 two young teenagers from the State of São Paulo produced awful writing graffiti in the famous statue. Information available at http://www1.folha.uol.com.br/fsp/1995/10/02/folhateen/2.html .

${ }^{9}$ On the original version article 65 sanctioned that "Foul or Graffiti or by other way tarnishing a building or an urban monument: Sanction: detention for three months - one year and fine".

${ }^{10}$ Ten years before Civil Law Code of 02', State University of São Paulo Procedural Law Professor stated: free translation "the fact is that in all cases there is a common panorama: a property right is violated, since the physical view of an estate is worthy of legal protection considering the preservation of its exterior aesthetics". In português: "o fato é que em todos os casos, há um panorama comum: um direito de propriedade é afrontado, já que uma acessão física alteada em um terreno é igualmente objeto de tutela jurídica no que concerne à preservação de sua estética exterior" MANCUSO, Rodolfo de Camargo. Aspectos Jurídicos da Chamada "Pichação" e Sobre a Utilização da Ação Civil Pública para Tutela do Interesse Difuso à Proteção da Estética Urbana. 1992, p. 161.

11 "This phenomenon we can denominate the fetishistization of the law speech, it means, through the dogmatic speech, the law is viewed as the law by the law, abstracting from the conditions (historicalsocial) that produced it" STRECK, Lenio Luiz. Hermenêutica Juridica e $(m)$ Crise. Uma Exploração Hermenêutica Da Construção Do Direito. 10a Ed. Rev., atual e ampliada. Porto Alegre: Livraria do Advogado Editora, 2011, p. 18.
} 
of anyone that unfairly possess or detains it". This same proprietor proposition would be held towards public ownership, considering graffiti's spontaneous tradition an illicit practice per se.

On one hand the graffiti practiced on a third party property, and without its consent, could not be subject to contracts (for instance, " $A$ " could not hire " $B$ " to create a graffiti on " $C$ " wall, without its knowledge or acceptance), since the same Brazilian Civil Code estipulates that the validity of a contract depends on the licit content of the obligation (article 104 of BCC).

On the other hand the Brazilian Copyright Law (9.610/98) erected a closed list of creations that would not be protected as copyrights (article $8^{\text {th }}$ ), in which it did not include art forms interpreted as illegal. This 'generosity' of the legislative branch was due to avoid morality issues to be raised as a free speech barrier: the obscene, the offensive, or the creation that was made without authorization is copyright matter just the same as regular art form.

The social practices, however, nurtured a counterculture ${ }^{12}$ posture against the Law in its static perspective, producing panel pieces and other graffiti art forms ${ }^{13}$ especially in public venues or in private property with exogenous position (walls and gates etc).

Verbi gratia, before all the construction sites promoted for Rio de Janeiro Olympics Games in 2016, the port zone of the city held a grey-ugly-abandonment scenario. A huge number of piled concrete blocks where drug addicts and the homeless coexisted, and drivers would pass thru in a hurry. In the words of Zygmunt Bauman, these highways and viaducts could be considered non-places ${ }^{14}$, a gap of real civilization, spaces between Rio's international airport and the downtown. In the 1980's a drifter later known as prophet "Gentileza" (meaning kindness) was responsible for more than fifty graffiti panels in this region, all of them embedded with poetry, bringing color and a "soul" for such a place. However, none of them had been contracted or authorized by the constituted powers, being produced - in fact - in face of the Executive branch's omission.

\footnotetext{
12 "since the property right isn't registered on the hearts, being simple creation of social conventions, there are inumerous reasons that induce men to violate such conventions" (free translation from) BECCARIA, Cesare. Dos Delitos e Das Penas. $2^{\text {nd }}$ Edition, Bauru: Edipro, 2010, p. 55.

13 In a part of Ronald Kramer's excellent introduction to this book: "In relation to the basic forms of graffiti and street art, it would not be unfair to assert that graffiti is typically name-based whereas street art is generally image based or pictorial (...) The presence of graffiti suggested that the line separating the art gallery from public space, a line that inhibits the widespread consumption of art, could be transgressed".

${ }^{14}$ In a free translation: "A non-place 'is a space empty of identity symbolic expressions, bonds and history: examples would include airports, freeways, anonymous hotel rooms and public transportation" BAUMAN, Zygmunt. Modernidade Líquida. Rio de Janeiro: Zahar Editora, 2001, p. 120.
} 
The panel texts reflected sincere messages of love, respect, generosity, the protection of environment, and many of the humanitarian values that seemed the opposite of the reality of the neglected neighborhood and its street community. In fact, one could say that (a) besides a small quantity of sculptures in public squares, and (b) hat excluding museums (usually attended by upper economic classes), these pieces provided some democratization ${ }^{15}$ to the access to art and culture $(\mathrm{a} 2 \mathrm{ac})^{16}$.

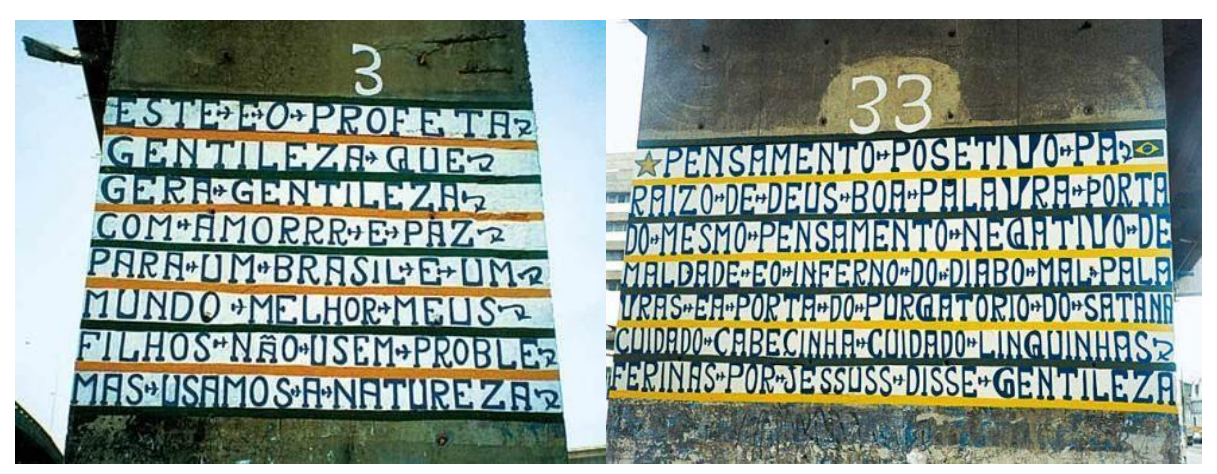

Circa two decades after, in the early 2000 (and four years after the artist Gentileza 'passed away'), those panels became famous and attracted tourism with its "magnetism", introducing diffuse pressure so that the municipality of Rio de Janeiro would recognize the oeuvre as part of its urban cultural protected sights.

Again, under a strict view of Brazilian property laws, the "prophet" had violated the ("absence") of aesthetical pattern - the horrible and homogeneous mortuary look - of that region, in a practice that could be condemned as a kind of public transgression. Under this static analysis, urban environment could only be changed with the consent of the public policies, and never unilaterally by a "beggar". In fact, another question raised by Gentileza's expressions is the complex issue of differing vandalism (as in a gang's symbol on a wall) from art (infungible expression of the human being) or adorn pieces.

Indeed, the panels produced in Rio's port zone are a quite simple (high contrast) example of "painted poetry", but in many other cases there is a grey area between (1) destruction and unlawful behavior towards (2) art's and pieces of creativity and originality.

\footnotetext{
${ }^{15}$ Article 23, V, of the Brazilian 1988 Constitution provides that (free translation): "The Federal, States, Federal Districts and Municipalities have common burden of: providing the means to access culture, education, science, technology, research and innovation".

16 Pictures available at: https://voluntarios.institutocea.org.br/pages/7387-profeta-gentileza-gentilezagera-gentileza-a-historia-do-profeta, accessed on august $3^{\text {rd }}$ 2018. There was no indication of the photographer.
} 
Actually, the absence of regulation could introduce the impression of aesthetic anarchy which, consequently, could result on excessive graffiti, visual pollution and the stress it creates on the overwhelmed metropolitan community. In Cole Porter's words, with this public inertia, "anything goes".

Factually, the aforementioned popularization of graffiti mildly impacted on the legislative branch that in the year 2011, amended Law 9.605/98 (art. 65, paragraph 2), to exclude the criminal sanctions for this sort of art if (i) there was a consent by the owner or tenant in the case of private property; or (ii) the authorization of the Executive Branch. Therefore, the literal limitation of the law preserved the higher "ground" of property towards artistic manifestation, since the will of the proprietor or the State would still dictate the autonomy of the arts men.

Would this kind of limitation preserve ${ }^{17}$ the core of the human right ${ }^{18}$, constitutional clause $^{19}$ or the Brazilian jurisprudence ${ }^{20}$ about free ${ }^{21}$ speech $^{22}$ ? Is this legal standard the best approach towards Brazilian cultural diversity constitutional provision? A prompt answer in such a manner empowering physical property (at the cost of immaterial creation) could support an

\footnotetext{
${ }^{17}$ In a restrictive view of such argument, The State Court of the Federal District, $1^{\text {st }}$ Appellation Chamber, Appellate Level Judge Aiston Henrique de Sousa, Appellation number 20160111102943APJ, Ruled in 12.07.2017, decided that: "It's not the function of the Public Powers to decide what is or not art. However, any artistic manifestation should be practiced on the limit to respecting other rights, such as, in the case, the right to preserve public properties (...) the Law doesn't represent a violation towards free artistic speech mentioned on the constitutional text, but, by the contrary, conforms it with the protection of property and the preservation of public goods (...)" (free translation).

${ }^{18}$ Preamble of the Universal Declaration of Human Rights: "Whereas disregard and contempt for human rights have resulted in barbarous acts which have outraged the conscience of mankind, and the advent of a world in which human beings shall enjoy freedom of speech and belief and freedom from fear and want has been proclaimed as the highest aspiration of the common people (...)".

${ }_{19}$ Brazilian 1998 Constitution, article 220 (free translation): "The manifestation of thought, creation, the expression and information, under any form, process or vehicle will not suffer any restriction, since it observe the disposed in this Constitution".

20 "Brazilian Constitution prohibits any kind of censorship" (free translation of) Supreme Federal Court, Pleno, Justice Carmen Lucia, ADI 4815/DF, decided 02.01.2016.

${ }^{21}$ In the same pathway as proposed in this paper a judicial discussion about the graffiti concluded: "The rights of freedom of manifestation and free speech of the intellectual and artistic activity, art. $5^{\text {th }}, \mathrm{IV}$ and IX of the Brazilian Constitution, must prevail over the protection of the public institutions, since they are the fundamental elements for the existence and functioning of the Democratic State of Law, contributing for the development of public debates and the free formation of citizenship will" (free translation) State Court of the Federal District, 6th Civil Chamber, Appellate Court Judge Vera Andrighi, Appellation number 20130110762308AP, Ruled in 06.10.2015.

22 "The idea of free speech has an affirmative side. It imposes constraints on what government may do, but it requires a certain kind of culture as well" SUNSTEIN, Cass R. Republic.com 2.0. New Jersey: Princeton University Press, 2009, p. XI.
} 
opposite conclusion in the cases of rap culture, remix and mashups towards intellectual property?

These are some of the questions one should propose when specific regulation - such as Law 9.605/98 - made by real estate owners (such as congressmen and members of senate) that hardly represent informal communities such as the street craftsman - is edited by the Legislative branch. Although one could easily refute a positive answer to the three questions above, it is important to recognize that different constitutional rights may collide in the hypothesis that one property right owner prefers not to receive the artistic gift. At the end of the day a conflict of interest must be solved prevailing one's autonomy act against another.

\section{ART, CO-WORKING AND DIACRONIC CONSTRUCTION OF GRAFFITI}

One of the most complex discussions on aesthetic theories is if one human manifestation constitutes, or not, a piece of art. To avoid the abuse of discretionary, subjective and purely arbitrary choices, the main requirement in the Brazilian law is that the piece is characterized by its originality. Besides being new the creation must be original - at least subjectively - considering de minimis contribution towards the state of $\operatorname{art}^{23}$, on the expressive part of the piece.

However, this doesn't mean that there isn't some collective convention - many times arbitrary - to decide what art is or isn't, and how it should be appreciated ${ }^{24}$. There are no doubts that during histories course the perception of art (and in an excluding way, what cannot be) has changed towards the evolution of social patterns ${ }^{25}$.

Besides the legal criteria (originality), and the social recognition ${ }^{26}$ aspect, one could also debate if the intentionality of the piece is necessary so that it can be determined as an art work. For example, tumbling ink - in purpose - in the middle of the city, so that cars would pass by

\footnotetext{
${ }^{23}$ BARBOSA, Denis Borges. Direito de Autor. Rio de Janeiro: Lumen Juris, 2013, p. 14.

24 "The artistic field, by its own operation, creates the aesthetic attitude without it could not function" free translation of BOURDIEU, Pierre. O Poder Simbólico. 15a Ed. - Rio de Janeiro; Bertrand Brasil, 2011, p. 286.

${ }^{25}$ BENJAMIN, Walter Benedix Schönflies. A Obra de Arte na Era da Sua Reprodutibilidade Técnica. In BENJAMIN, Walter Benedix Schönflies. DETLEV, Schöttker. SUSAN, Buck-Morss MIRIAM, Hasen. Benjamin e a obra de arte: técnica, imagem, percepção. Translated by Marijane Lisboa e Vera Ribeiro; organização Tadeu Capistrano. Rio de Janeiro: Contraponto, 2012, p. 13.

26 "The essential point remains the same: one sort of thing is only money during a long time if its is accepted as money. And what applies to money also applies to social and institutional reality in general" free translation of SEARLE, John R. Mente, Linguagem e Sociedade: filosofia no mundo real. Translated by F. Rangel, Rio de Janeiro: Rocco, 2000, p. 106.
} 
and spread colors around; or, an accident involving a truck full of ink; would not be considered properly graffiti or any other kind of art, although it may look like a post-modern approach towards aesthetics ${ }^{27}$.
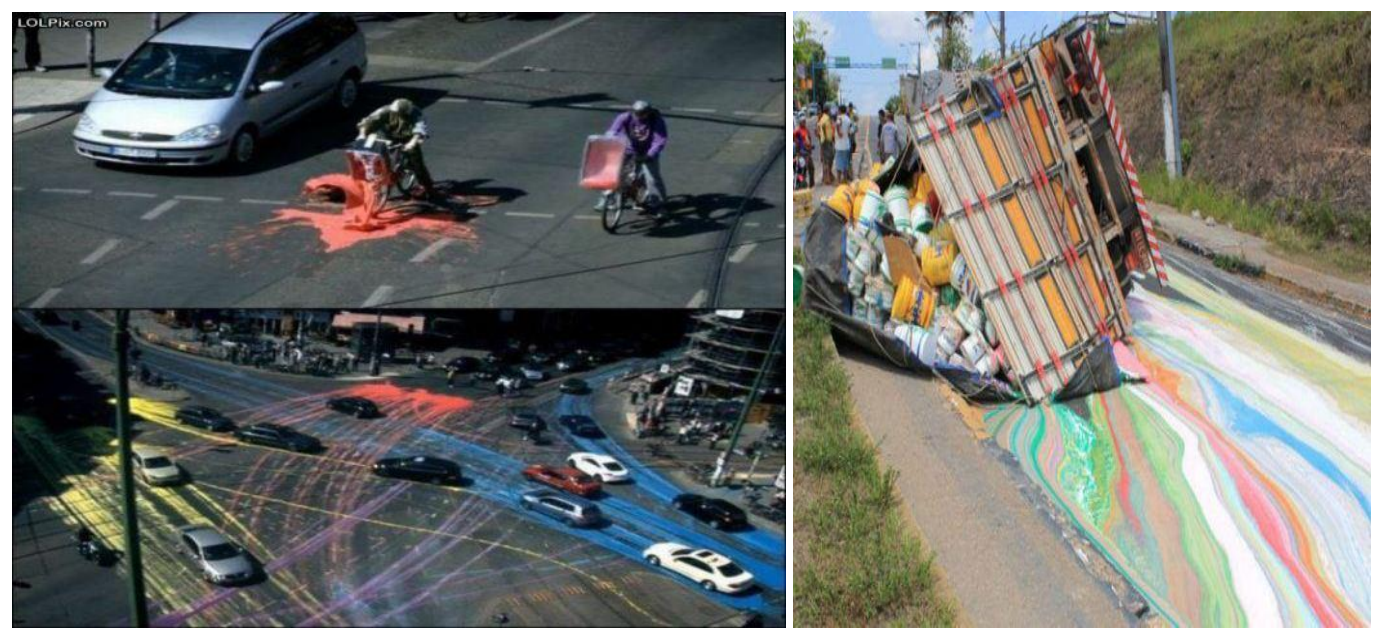

In the street art context, the same could be argued concerning if one's intervention (even with specific intent) in nature is art, and therefore, being protected by copyright. Could the simple initials of a gang ${ }^{28}$ or cussing $^{29}$ in a wall be considered art? Probably it could not and it has nothing to do with a moral clause restriction in Brazilian Law. In fact these would be cases of lack of originality, besides the bad taste of its author. These practices, therefore, would reasonably be sanctioned as a criminal and civil violation towards the property owner.
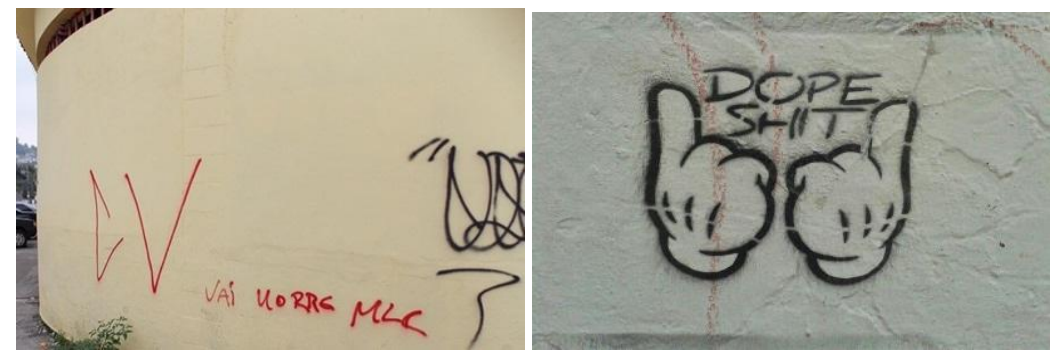

\footnotetext{
${ }^{27}$ The following pictures are available at: http://humortadela.bol.uol.com.br/memes/94202, accessed on august $3^{\text {rd }}$ 2018. There was no indication of the photographer.

28 The "CV" initials in the wall means "Comando Vermelho"- or Red Command, one of the most oppressive and feared narcotics gangs in Brazil.

29 Available at: https://br.pinterest.com/spimgarrido/street-art-graffiti-guadalajara/, there was no indication of the author of the photography.
} 
There could also be doubts concerning if a piece subject to prompt destruction by (i) the author himself, (ii) overpainting by the owner of the wall/gate/building, (iii) overlapping graffiti by third parties, (iv) removal by the State, or (v) erased by climate changes, wind and rain, could pursue a copyright protection. Is there any kind of legal trade off towards time vs. art?

Even if the street masterpiece resists for a few seconds this would not stop its protection of the existential and patrimonial rights of copyright, if its merits attended the originality requirement.

In fact, there are other manifestations of art in Brazil that are commonly made to exist for a really short time, such as sand or food sculptures. Art doesn't need to be eternal such as life itself is not ${ }^{30}$.
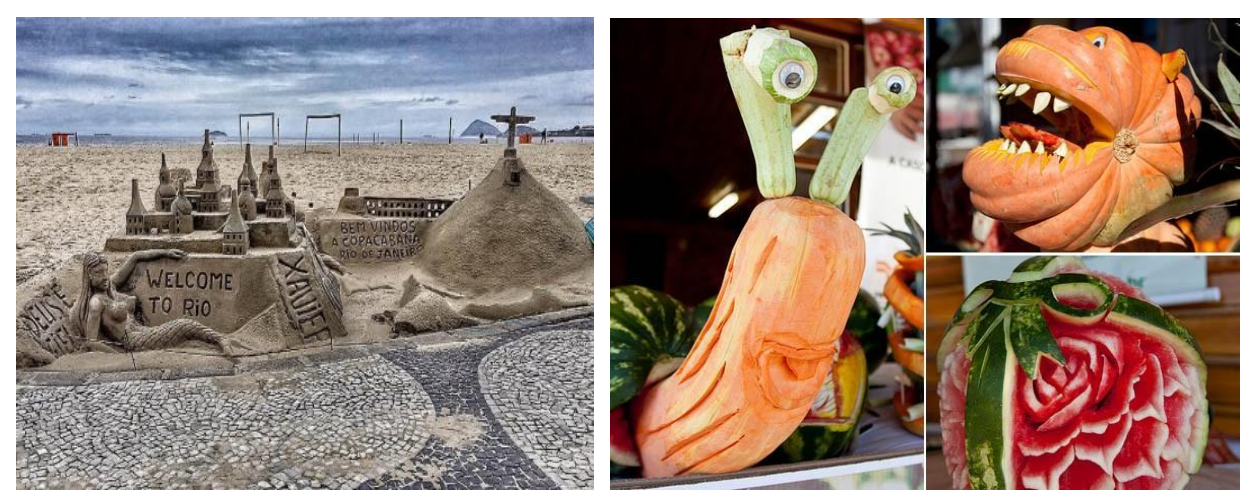

The law has not a de minimis criteria of time lapse so that an oeuvre may require protection, even if the former piece can only be accessed by the memories of wanderers, the author, or by the author of the photography that 'registered' that moment of art. The external material in which a piece is done can itself be destined to consumption, or (self)destruction, without exterminating constitutional and legal protection as art per se.

Another interesting character of graffiti art - although still quite exceptional and controversial - is its specific openness towards a collective creation: one person starts the piece so that another can continue the work, just as a network community ${ }^{31}$. The frailty of the piece

\footnotetext{
30 The following pictures were available at: (i) https://pormimanalu.wordpress.com/2016/03/08/rio-dejaneiro-copacabana-e-museu-do-amanha/, photographer VASCONCELOS, Ana Luiza; (ii) http://g1.globo.com/rs/rio-grande-do-sul/noticia/2012/08/frutas-e-hortalicas-viram-esculturas-naexpointer-no-rio-grande-do-sul.html, there was no indication of who was the author of the photography. ${ }^{31}$ In a text that concerns internet creation but can, perfectly, fit in the context of graffiti: "The result is a flourishing nonmarket sector of information, knowledge, and cultural production, based in the networked
} 
being available for everyone, at anytime, also conducts the spirit of a probable co-authorship (even if it is involuntarily). Besides the physical exposure, the Brazilian Copyright Law diminishes the protection towards the pieces that are permanently exposed in public venues, since the author/holder cannot avoid third parties to represent them in other art pieces (article 48 of $B C L)$, although, according to commentators ${ }^{32}$, this reproduction shall not be for economic purposes.

In the other hand, if graffiti itself has had no trouble in been considered an art form in Brazil, many of the legal issues impact over the authorship ${ }^{33}$ and the burden of proof for those who allege $i^{34}$, since many of the amazing panels are not "signed" by the craftsmen. The lack of signature can be explained not by the desire to remain anonymous, but of the fear of being punished by the unauthorized practice toward third parties property. However, if the signature is explicit on the graffiti piece, there will be no issue concerning the paternity/maternity of the creation (article 12 of the Brazilian Copyright Law). Once the piece is created the protection (economic and existential) is automatic without the need of registration, according to national (article 18 of the Brazilian Copyright Law) and international legal standards ${ }^{35}$.

environment, and applied to anything that the many individuals connected to it can imagine. Its outputs, in rum, are not treated as exclusive property. They are instead subject to an increasingly robust ethic of open sharing, open for all others to build on, extend, and make their own" BENKLER, Yochai. The Wealth of Networks. How Social Production Transforms Markets and Freedom. London: Yale University Press, 2006, p. 7.

${ }^{32}$ ABRÃO, Eliane Y. Direitos de Autor. 2a Edição, Rio de Janeiro: Migalhas, 2014, p. 359

${ }^{33}$ In an important decision of the State Court of São Paulo (free translation) "It can be noticed, therefore, that the decriminalization of the conduct of graffiti urban buildings contributed for the development of this activity, that became to be seen, in a social venue, as a cultural and artistic manifestation, and in the individual manner became protected by copyright law. Therefore, the legal graffiti, that one practiced in the manner regulated by article 65, paragraph 2, of Law 9.605/98, called by the appellee as graffiti-art is inserted on the concept established by article 7 of Law 9.610/98 (...) However, if the appellee did not identify their graffiti, there is no way to recognize that the defendant's practice [of copying the panel without the consent of the plaintiffs] was illegal (...) The author that doesn't identify its piece, available on walls and public venues, cannot expect to receive copyright protection (...)" State Court of São Paulo, 10th Chamber of Private Law, Appellate Level Judge Carlos Alberto Garbi, AC 01390363920098260100 , decision published at 02.25.2014.

34 "It is important to notice, however, that the court level decision correctly ruled that the Plaintiff uses, on the artistic world of graffiti art of the pseudonym "NdRua" [NdStreet], and that he is recognized by the specialized critics for his work and, still, that Motorola used some graffiti in the walls of São Paulo Street to its publicity (...) However, analyzing the proof in the law suit, it is impossible to conclude differently than the absence of demonstration by the Plaintiff/Appellee of the authorship of those graffiti so that he could be awarded damages (...)" State Court of São Paulo, 3rd Chamber of Private law, Appellate Court Level Judge. Beretta da Silveira, AC 0180558802008260100, decision published at 02.22.2011.

${ }^{35}$ For example on European Standards: BENTLY, Lionel \& SHERMAN, Brad. Intellectual Property Law. $2^{\text {nd }}$ Edition, Oxford: Oxford University Press, 2004, p.115. 


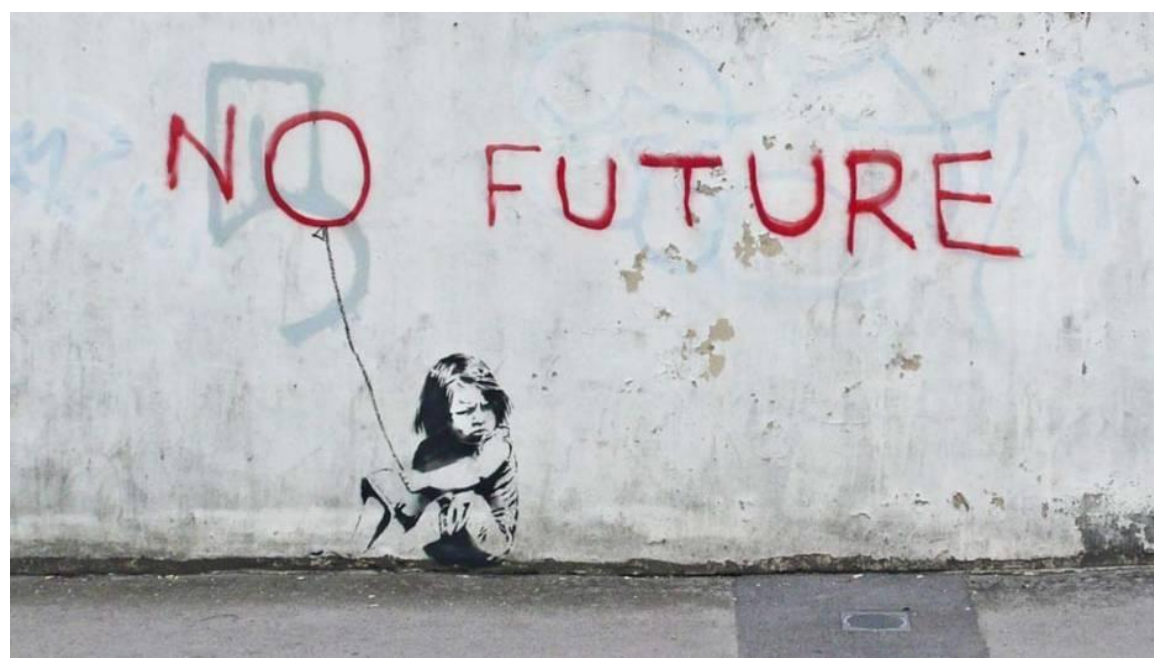

$\left(\right.$ Banksy $\left.^{36}\right)$

Of course that "collective work" is not restricted to a synchronic hypothesis, where two or more artists/authors work together simultaneously, such as in this text that is written by two different scholars, joining forces.

Actually street graffiti are excellent examples of the art piece that can be a collective work (composed piece ${ }^{37}$ ) throughout a diachronic phase: a smaller piece is overwritten or even continued by another, constructing a larger feature or body; one piece that "dialogues" with another in an universality approach. Therefore, the artwork itself can always be seen as partially complete, since the interpretation of the work is done by those who appreciate ${ }^{38}$ the piece.

However, when a third party interacts with one's graffiti creation, without a proper consent, this act could be interpreted as a violation towards the Brazilian Copyright Law Integrity Clause (article $24^{\text {th }}$, IV), which is protected as a personality/existential right ${ }^{39}$.

\footnotetext{
${ }^{36}$ Available at: https://veja.abril.com.br/galeria-fotos/banksy-2/, accessed at 03.20.2018, at 16:41.

${ }^{37}$ CHAVES, Antônio. Criador da Obra Intelectual. São Paulo: LTr, 1995, p. 178.

38 "The interpretation of the painting and of the novel involves, only, the comprehension of who looks or reads" (free translation of) GRAU, Eros Roberto. A Musica e 0 Direito. Available at: https://oglobo.globo.com/opiniao/a-musica-o-direito-12465403\#ixzz54ZO4Zdrr, accessed on
} 01.18 .2018 , at 17:25.

39 COSTA NETTO, José Carlos. Direito Autoral no Brasil. 2ª̣, Edição, São Paulo: FTD, 2008, p. 134. 
THE REACTION AGAINST THE SOCIAL PRACTICE OF GRAFFITI: THE SÃO PAULO CASE

Elected in October of 2016, in the overture of 2017 João Agripino da Costa Doria Junior, a right winged politician that became relatively famous throughout his doubtful television program destined for wealthy businessmen, took office at the municipality of São Paulo, the largest, most populated and the economic center city of Brazil. Within his main proposals, Mr. Doria 'sold' the idea - in a marketplace of "law and order" fans - that one of the main villains ("it is the enemy of the city" ${ }^{\prime \prime 0}$ ) of São Paulo was its abandoned appearance, and that graffiti was responsible for such bad environment. To 'revenge' what he understood as an assault against the public aesthetic values, Mr. Doria decided to paint over the graffiti of the City of São Paulo with plain grey ink.

In fact, in his first days of office he dressed himself as the municipality Garbage Men (to impersonate a simple worker), called the press, and 'erased' long panels of graffiti on a tradition street art location at the downtown. In his own words: "I painted with huge pleasure three times the zone (...) to demonstrate my endorsement to the town politics and to repudiate the graffiti practitioners $^{\prime \prime 1}$. It is always hard to override the talent of populist political behavior in SouthAmerica.
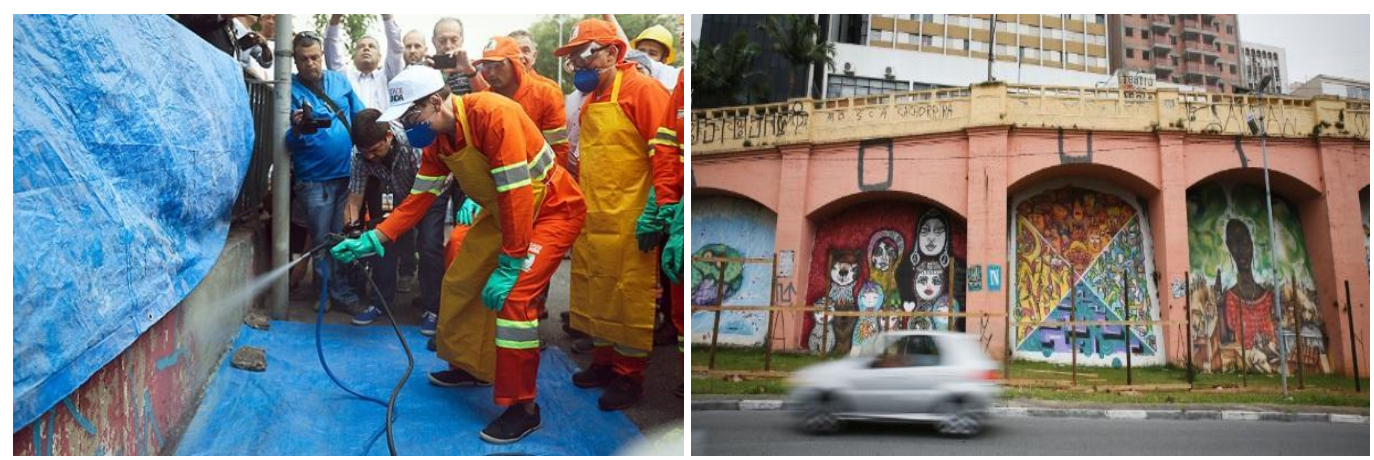

In a Latin version of Rudolph Giuliani's renowned policy, Mr. Doria stated: "If they prefer to continue graphitizing the city, they'll receive the penalties of the Law. It's zero tolerance".

\footnotetext{
40 http://www1.folha.uol.com.br/cotidiano/2017/02/1858612-justica-proibe-doria-de-cobrir-grafite-semprevia-consulta-ao-conpresp.shtml, accessed on 01.18.2018, at 17:50.

${ }^{41}$ Accessed at https://noticias.uol.com.br/cotidiano/ultimas-noticias/2017/01/14/doria-manda-apagargrafites-dos-arcos-do-janio-e-da-av-23-de-maio.htm, on the 01.18.2017 at 17:37. There was no indication of the author of the photography.
} 
Factually, with a coherent attitude towards his speech, Mayor Doria promptly sanctioned a municipal Law Bill (55/2005) that raised the fines against the graffiti painted in public or private buildings, to reach the considerable sum of 10,000 Brazilian Reais - circa US\$3,000.

Unsatisfied with this new approach against more than twenty years of the street popular practice, some citizens together proposed ${ }^{42}$ a collective ${ }^{43}$ law $^{44}$ suit $^{45}$ against the Municipality of São Paulo aiming to stop, immediately, any conduct of erasing the graffiti, well as to establish that the Municipality Counsel of Historic Sites, Cultural and Environmental Preservation of São Paulo (CONPRESP) as the exclusive Public Authority that could decide about the removal of such art. This, in fact, is possible since the State itself doesn't have the monopoly to protect public interests ${ }^{46}$, so that citizenship can contribute with important collective litigation.

Before deciding about the injunction plead by the Plaintiffs, the State Judge heard the previous defense of the Municipality of São Paulo stating (a) that another governmental committee (CPPU) was the responsible for the protection of urban venues, (b) that graffiti was not a matter of cultural site protection, and (c) that the mayor had the proper authority to remove the graffiti unilaterally.

Notwithstanding, the Public Prosecutor of the State of São Paulo agreed with the Municipality of the State Capital and did not endorse the merits of the aforementioned class action.

However, analyzing the documents presented by the Plaintiffs, Defendant and the Public Prosecutor, the State Judge Dr. Adriano Marcos Laroca granted the preliminary injunction to (a) avoid any new graffiti removal by the Municipality, with (b) a "stimulating" sanction of $R \$ 500,000$ per day and (c) contempt of court in case of non-compliance. In the Judge's opinion,

\footnotetext{
${ }^{42}$ The use of this collective law suit is held as a high form of the republican values: SARMENTO, Daniel. SOUZA NETO, Cláudio Pereira de. Direito Constitucional: teoria, história e métodos. 2a Edição, Belo Horizonte: Fórum, 2016, p. 219.

${ }^{43}$ Historically, however, commentators only analyzed the use of collective law suits against graffiti, never to protect it: MANCUSO, Rodolfo de Camargo. Aspectos Jurídicos da Chamada "Pichação" e Sobre a Utilização da Ação Civil Pública para Tutela do Interesse Difuso à Proteção da Estética Urbana. 1992, p. 172

${ }^{44}$ Federal Constitution of Brazil, 1998, article $5^{\text {th }}$, LXXIII: "any citizen has legitimacy to file a popular law suit that aims to declare void any act that represents damages against public property (....) to the environment to historic and cultural sites" (free translation).

45 Popular Collective Law Suit number 1003560-75.2017.8.26.0053, before the 12nd Public Finances Court, State Court of São Paulo.

${ }^{46}$ CUNHA. Leonardo José Carneiro da. A Fazenda Pública em Juízo. São Paulo: Dialética, 2008, p. 33.
} 
there is an enormous difference between "pichar" 47 - which would be an act of vandalism - and graffiti, which would be an "urban artistic expression (street art)", a "transgression" kind of art that would whistle-blow the social inequalities. The decision also stated that graffiti would be different from a mural art, since the latter would be hired and previously authorized by the Public authorities. Notwithstanding, the decision mentioned that the transitory character of graffiti does not prevent it from being recognized as a public cultural asset, while it is not substituted by another art form; and that the public policies of urban and cultural development has to result from the cooperation between State and Society, never to be imposed by the first to the latter as a "prejudice and authoritarian" conduct.

Unsatisfied with the court level decision, the Municipality of São Paulo presented an interlocutory appeal, and obtained an important 'victory' towards the $6^{\text {th }}$ Chamber of Public Law Court, of the State of São Paulo ${ }^{48}$. Although this kind of provisory decision doesn't comprehend all the details and merits of the case, the Appellate Court Judge sustained that the fact that graffiti is considered a form of art wouldn't be sufficient to understand the removal provided as a violation to the cultural and artistic historic sites ${ }^{49}$.

Although a merits decision has not been held, yet, by the trial level court, the interlocutory decision that was reverted by the Appellate Level raised an interesting discussion concerning the constitutional rights involved on the matter. Specifically in article $23^{\text {rd }}$, III and IV, of 1988 Brazilian Constitution (B.C.) there is a provision that express a simultaneous power to the Federal, State and Municipality governments to "protect the documents, the oeuvres and other goods of historic, artistic and cultural value, the monuments, the natural and notable landscapes and the archeological sites" and to "avoid the flee, the destruction (...) of artworks (...)".

Since the Appellate Level interlocutory ruling expressly understood graffiti as a form of art, it is quite hard to state that the authorization for the Municipality of São Paulo continue its erase acts in graffiti walls compliant with its general constitutional duty (1) to avoid "the destruction" of art pieces; (2) to "protect the popular cultural manifestation" article $215, \S 1^{\text {st }}$ of

\footnotetext{
47 In the same manner of distinction, State Court of Rio Grande do Sul, Criminal Appellate Chamber, Appellate Level Judge Luiz Gustavo Zanella Piccinin, Appellation number 71006580427, Ruled in 06.19.2017.

48 State Court of São Paulo, 6th Chamber of Public Law, Appellate Court Level Judge Dr. Maria Olívia Alves, Al 9.605, Ruled in 08.21.2017.

${ }^{49}$ However the content of this second decision was "packed" with some conservative opinions: "since what has been seen is a true growing degradation of public properties, with acts of vandalism that cause true sadness to the population" (free translation).
} 
the $\mathrm{BC}$; and (3) with its specific burden to "promote the protection of the historic-cultural local sites $(. . .)^{\prime \prime}$, determined by article 30 , IX, of the BC.

To avoid a nonlinear argument, if the literal approach towards interpretation is used by one to protect property rights, the same technique would prevent the State or the Proprietor to destroy ${ }^{50}$ graffiti.

In fact, the constitutional provision concerning the State Actions towards Cultural goods previews, even, the use of expropriation (article $216, \S 1^{\text {st }}$ of $B C$ ) to protect the artistic assets, but never the use of force to annihilate art expressions. These thoughts are not seriously impacted by the common auto limitation towards a more incisive judicial review or the separation of Powers ${ }^{51}$ doctrine, since the supremacy ${ }^{52}$ of the Constitutional Law should be recognized towards the Civil Code (and its property rights).

\section{THE PROMOTION OF THE SOCIAL PRACTICE OF GRAFFITI: THE RIO DE JANEIRO CASE}

In the quite opposite context of São Paulo, the city of Rio de Janeiro has maintained its recent tradition of promotion of the social practice of graffiti. In February $18^{\text {th }}, 2014$, the city Mayor, Mr. Eduardo Paes, published a Decree (Decree n. 3.8307/2014) by which (i) graffiti was recognized as a cultural expression ${ }^{53}$, (ii) it was created a specific city council which is responsible for the continuous revitalization of the touristic public areas ${ }^{54}$ and (iii) the practice of graffiti was expressly authorized on every public area (walls, lighting poles, columns and so on), provided that the area is not qualified as historical patrimony ${ }^{55}$.

\footnotetext{
${ }^{50}$ In an interesting case where after a neighborhood disagreement one was sanctioned in $R \$ 3.000$ (less than one thousand dollars) for the destruction of an authorized graffiti, the State Court of Rio Grande do Sul barely recognized the importance of this sort of art piece: TJRS, $9^{\text {th }}$ Civil Law Chamber, Appellate Level Judge Carlos Eduardo Richinitti, Appellation number 70067768580, Ruled in 04.13.2016.

${ }^{51}$ MENDES, Gilmar Ferreira \& BRANCO, Paulo Gustavo Gonet. Curso de Direito Constitucional. 11a Edição São Paulo: Saraiva, 2016, p. 43.

52 BARROSO, Luís Roberto. O controle de constitucionalidade no direito brasileiro: exposição sistemática da doutrina e análise crítica da jurisprudência. $6^{\text {th }}$ Edition, São Paulo: Saraiva, 2012, p. 22.

53 Decree n. 3.8307/2014: "WHEREAS GRAFFITI, without prejudice to public or historical patrimony, without publicity (reference to brands or products), without pornographic, racist or otherwise prejudiced content, without illegal apologies and religious offenses is recognized as an artistic and cultural manifestation that values the City and inhibits vandalism".

${ }^{54}$ Decree n. 3.8307/2014, article 3.

${ }^{55}$ Decree n. 3.8307/2014, article 4: "It is authorized to use the following public spaces as a stimulus for the practice of GRAFFITI and Street Art: poles, columns, gray walls (since they are not considered historical heritage), blind walls (without doors, windows or other opening) and works sidings.".
} 
This Decree was one of the many policies carried by the city of Rio de Janeiro, due to the World Cup (2014) and the Olympics (2016). The city intended to promote a more globalized 'spirit' in its touristic areas and the legal recognition of graffiti was a very important step. Some areas of the city have changed dramatically due to (and/or with the aid) of graffiti and these venues became quite popular.

One of those regions was the port area, for instance. Before the Olympics, that area was filled with abandonment - abandoned warehouses, streets and even people. It can not be said that the graffiti were solely responsible for its revitalization. Nonetheless, after the Estate rearranged the area (with infrastructure works and landscaping), the graffiti were the main purpose why thousand of people visited (and still visit) the port.

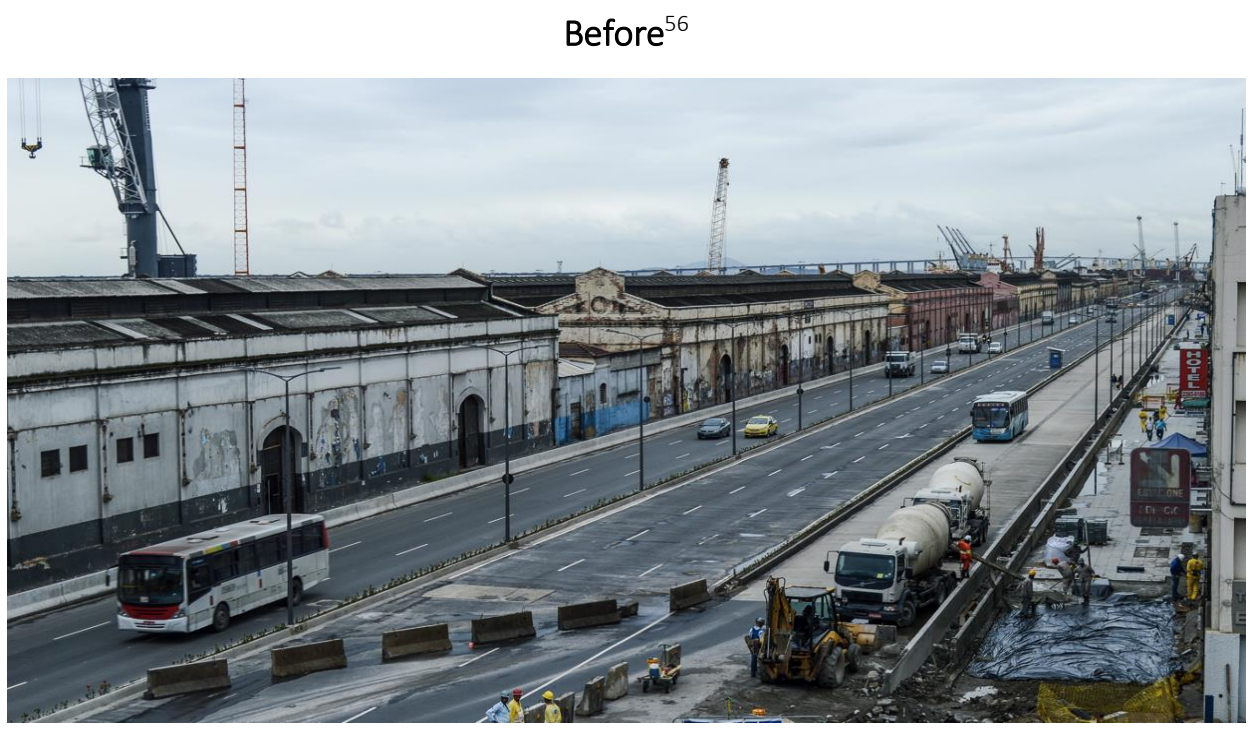

${ }^{56}$ Picture available at: http://portomaravilha.com.br/viaexpressa. 

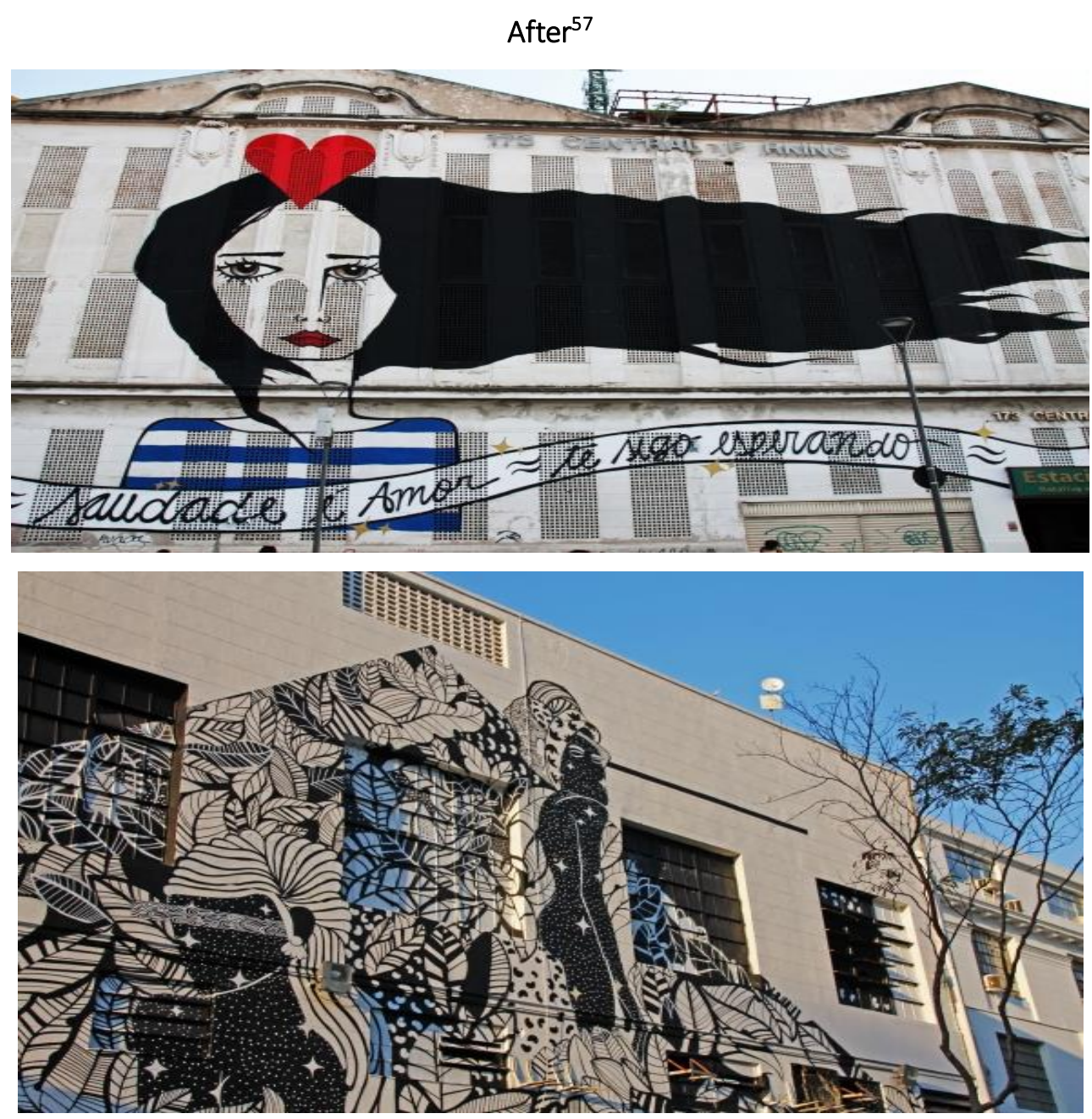

It must be stressed that the graffiti acceptance is not circumscribed only at the touristic areas or to popular artists. An independent project, called \#StreetArtRio has tracked more than twenty thousand graffiti only in the city of Rio de Janeiro ${ }^{58}$, and more than seven hundred artists in the whole State of Rio de Janeiro ${ }^{59}$. Therefore, although there is no comprehensive data related to the graffiti acceptance at the Brazilian society, it could be argued that the graffiti was "naturalized" after the incentive from the State - specially if one takes into account that graffiti has the support from the media since $1990 s^{60}$, and it was only earlier that it got more attention.

57 Pictures available at: http://portomaravilha.com.br/noticiasdetalhe/Galeria-arte-urbana-\%C3\%A9aberto:4597. Graffiti from Rita Wainer and Camila Camiz, respectively.

${ }^{58}$ Available at http://streetartrio.com.br/mapa/\#cidades.

${ }^{59}$ Available at http://streetartrio.com.br/artistas/.

60 Schlecht, N. E. (1995). Resistance and appropriation in Brazil: How the media and "official culture" institutionalized Paulo's grafite. Studies. Latin American Popular Culture, 14, 147-170. 
Then, it could be viewed that the policy stated at the Decree, in contrast with São Paulo's "witch hunter" campaign, tend to solve the graffiti debate in a more smooth way. It does not mean that all the problems would be extinguished. There are still discussions about graffiti and privet property and graffiti appropriation from third parties (see H\&M-graffiti debate ${ }^{61}$ ), for example. Nonetheless, this policy is a step forward into the comprehension of this "new" form of art and cultural expression - it should be reminded that one of the most famous at expression in the present days, photography, was not qualified as protected work at the first two versions of the Berne Convention ${ }^{62}$.

\section{CONCLUSION}

Besides the Brazilian Constitution mainstream interpretation itself, there has been a long tradition of administrative recording ${ }^{63}$ of historic sites, buildings and oeuvres in public venues, so as to treat general (architectural, artistic etc) culture with prestige ${ }^{64}$ and caution. It is important to note that the eventual acts of recording are also controlled by judicial review ${ }^{65}$, so as to avoid unlawful or abusive discretionary application by the Public Authorities since this administrative act impacts on the liberty of the property owners.

One reasonable, proactive and cooperative attitude provoked by State Powers would be the use of public policies such as (i) "graffiti zones", especially in "dead" public spaces on the highways or parks; (ii) open and incentivized competition (with expert juris, public biding and prizes) between graffiti arts men; and (iii) museums dedicated towards this dynamic kind of art. With such promotions, gradually the social and discriminative aura of illegality would fade away from the graffiti practices. It may become a regular art form such as every other kind.

\footnotetext{
${ }^{61}$ Available at https://www.nytimes.com/2018/03/15/nyregion/brooklyn-graffiti-hm-lawsuit.html.

${ }^{62}$ Available at https://cyber.harvard.edu/people/tfisher/IP/Berne\%20History.pdf.

63 In portuguese this act of cultural protection is called "tombamento": It is a hypothesis where "The state will intervene on private property to protect the cultural site, with the objective to preserve the national memory" (free translation of) SCATOLINO, Gustavo. TRINDADE, João. Manual de Direito Administrativo. 3a Edição, Bahia: Editora Jus Podivm, 2015, p. 891

64 "The civilized State has to appraise culture (...)" (free translation) MOREIRA NETO, Diogo de Figueiredo. Curso de Direito Administrativo. 16a Edição, Rio de Janeiro: Forense, 2014, p. 418.

${ }^{65}$ MEIRELLES, Hely Lopes. Direito Administrativo Brasileiro. 39th Edition, São Paulo: Editora Malheiros, 2013, p. 647.
} 
While such ideas are not implemented, the same Brazilian Civil Law Code (BCC) foresees an interesting provision that permits a private compulsory form of property acquisition ${ }^{66}$, throughout an antique Roman law institute called "especificação". In article 1.269 of BCC, it is regulated that if one works on a third party property, and throughout the use of the matter obtains new specimen, this one will become the owner of the work if it pays for the damages (expropriation) suffered. Imagining the application of the institute towards graffiti, one should not imagine that the artist wants to purchase the wall or fence itself, but to protect - exclusively - the surface where the art panel was painted. Therefore, limiting the payment for the surface of the wall or the construction is profoundly more affordable than purchasing the whole property, or the entire wall.

Unfortunately, this solution would demand a minimum economic capacity of those interested where the scarcity of capital is the common ground. However, the alternate combination of especificação with the registration of the public sites could balance the needs between the wealthy and the economic frailties. In the registration hypothesis, usually there is a huge - even complete - Property Ownership Tax (payed annually) Exemption, creating an interesting trade off.

In the cases none of the above solutions could be applied, Municipal, State and Federal Authorities could include in their annual budgets sufficient provision to expropriate the most important artistic surfaces (graffiti) over third (private) parties' construction, fences and walls. Such State economic investments would represent the acquisition of communitarian, diachronic, and network spirited pieces, protecting and incentivizing the development of one popular art movement of the late twentieth century.

The fact is that throughout Brazilian short graffiti historic evolution, the strength of the criminal Law became mild towards a cultural and inclusive approaches by social practices and communities. In the twenty first century it would be contradictory - towards the despotic exile after a long period of tyranny - to use State power to promote the destruction of masterpieces, censorship, or to diminish democratic access to street art. If the State fails to uphold its constitutional duties to promote artistic movements, it should restrict itself to intervene ${ }^{67}$ against cultural manifestations such as graffiti.

${ }^{66}$ In Brazilian Law private compulsory acquisitions are quite unusual, and between such forms of purchasing property the collective adverse possession case of art. 1.228, paragraph $4^{\text {th }}$, of the Civil Code, and the closing of a previously open company throughout a mandatory selling of one's share have been those which attracted the interest of the specialized doctrine.

${ }^{67}$ OLIVEIRA, Regis Fernandes de. Direito e Arte. São Paulo: Malheiros, 2017, p. 136. 
Revista de Direito da Cidade

vol. 11, ำ 1. ISSN 2317-7721

DOI: $10.12957 /$ rdc.2019.36534

Trabalho enviado em 03 de agosto de 2018

Aceito em 03 de setembro de 2018 